International Journal of Canadian Studies

Revue internationale d'études canadiennes

INTERNATIONAL JOURNAL OF CANADIAN STUDIES

\title{
Where is There? The Canadianization of the American Media Landscape
}

\section{Eric Weeks}

Numéro 39-40, 2009

Culture - Natures in Canada

Culture - natures au Canada

URI : https://id.erudit.org/iderudit/040824ar

DOI : https://doi.org/10.7202/040824ar

Aller au sommaire du numéro

\section{Éditeur(s)}

Conseil international d'études canadiennes

\section{ISSN}

1180-3991 (imprimé)

1923-5291 (numérique)

Découvrir la revue

\section{Citer cet article}

Weeks, E. (2009). Where is There? The Canadianization of the American Media Landscape. International Journal of Canadian Studies / Revue internationale d'études canadiennes, (39-40), 83-107. https://doi.org/10.7202/040824ar
Résumé de l'article

Alors qu'un nombre croissant de films américains et de productionstélévisuelles sont tournés au Canada, cet article soutient que même si lacanadianisation du paysage médiatique américain obéit à une logique économique, ellenuit en fait au patrimoine culturel des deux pays. Il examine, d'une part,les raisons qui contribuent à la tendance du transfert de la production au Canadaet, d'autre part, la façon dont des événements récents ont influé sur lamigration d'Hollywood vers le nord. En outre, les représentations" authentiques » des lieux sur les grands et petitsécrans sont explorées, tout comme les effets économiques de ces productionsextérieures la relocalisation de la production des films et des émissionstélévisées en raison des faibles coûts ailleurs dans le monde - sur l'identitéculturelle nationale et sur l'accueil de la part du public, tant aux États-Unisqu'au Canada. 


\title{
Eric Weeks
}

\section{Where is There? \\ The Canadianization of the American Media \\ Landscape}

\begin{abstract}
An increasing number of American film and television productions are filmed in Canada. This paper argues that while the Canadianization of the American media landscape may make financial sense, the trend actually causes harm to the cultural landscape of both countries. This study examines reasons contributing to the tendency to move production to Canada and how recent events have impacted Hollywood's northern migration. Further, "authentic" representations of place on the big and small screens are explored, as are the effects that economic runaway productions-those films and television programs that relocate production due to lower costs found elsewhere-have on a national cultural identity and audience reception, American and Canadian alike.
\end{abstract}

\section{Résumé}

Alors qu'un nombre croissant de films américains et de productions télévisuelles sont tournés au Canada, cet article soutient que même si la canadianisation du paysage médiatique américain obéit à une logique économique, elle nuit en fait au patrimoine culturel des deux pays. Il examine, d'une part, les raisons qui contribuent à la tendance du transfert de la production au Canada et, d'autre part, la façon dont des événements récents ont influé sur la migration d'Hollywood vers le nord. En outre, les représentations « authentiques » des lieux sur les grands et petits écrans sont explorées, tout comme les effets économiques de ces productions extérieures - la relocalisation de la production des films et des émissions télévisées en raison des faibles coûts ailleurs dans le monde - sur l'identité culturelle nationale et sur l'accueil de la part du public, tant aux États-Unis qu'au Canada.

"We make some budget cuts, we shoot in Vancouver."

"No, we're not shooting in Vancouver. I'm drawing the line on the insanity. Vancouver doesn't look like anything. Doesn't even look like Vancouver. It looks like Boston, California."

(Perry and Whitford) 
In the pilot episode of the NBC television program Studio 60 on the Sunset Strip (2006-2007), two main characters argue over the future of one of their film projects. As financing is questionable, the possibility of filming in Canada-Vancouver in particular-is raised, only to be quickly overruled due to the supposed lackluster nature of that city as a filming location. The above quote from that episode serves as a fitting introduction to this paper's topic, namely an analysis of the benefits and drawbacks of American film and television productions filmed in Canada. However, while the Canadianization of the American media landscape may make financial sense, the trend actually causes harm to the cultural landscape of both countries.

To argue this point, I build from the approaches advanced by Jim Leach and Mike Gasher, as well as Andrew Higson's concept regarding "how actual audiences construct their cultural identity in relation to the various products of the national and international film and television industries" (279). When examining Hollywood's impact on the establishment of a distinguishable Canadian film genre and national identity, Leach notes that "Since Canada is so close to the United States, is claimed by Hollywood as part of its domestic market, and is now increasingly tied to the U.S. economy through free trade agreements, it is hardly surprising that the discourse on the national cinema often takes on a paranoid tone" (475). In Hollywood North, Gasher focuses on British Columbia's attempts to lure Hollywood productions to their cities and towns, and the ways in which the province has situated itself and its economy as an attractive option for filming locations. However, these texts, like much of the existing work on the subject, study the situation from a Canadian point of view. Similarly, the bulk of the related scholarship examines the overall Canadian film industry, investigating economic factors and indigenous aspects, as well as providing historical analysis and review. When the filmed landscape is discussed, it is often in comparison to art and paintings, focusing more on broad, sweeping vistas or the framing and use of color and lighting.

In contrast, I intend to approach the topic from an American standpoint, not only studying the American influence on Canadian culture, but more importantly, the Canadian impact on American culture through the mediated landscape. Although the United States does not have an official national language, English is the primary language used in business, education, and cultural production. ${ }^{1}$ Therefore, this paper will focus on American and Canadian Anglophone films and television programs so as to find a common linguistic ground and employ examples that are accessible by the majority of both countries' populations. I will examine the reasons-including economic, logistical, and visual-that contributed to the tendency to film U.S. productions in Canada, particularly since the 1990s, and how more recent events, such as the 9/11 attacks and the U.S. and Canadian dollars reaching parity in September of 2007, slowed, and even 
reversed, the northern migration. I will explore the shift in "authentic" representations of place as seen on the big and small screens, and the effect economic "runaway" productions have on audiences, American and Canadian (specifically English-speaking Canadians), as well as public perceptions of location and the built and natural environments. ${ }^{2}$ It is important to differentiate the two types of runaway productions-creative and economic, the latter of which will be discussed here. Creative runaways film in a certain location because that setting is essential to the plot-such as filming in Paris, in front of the Eiffel Tower, a feature not found elsewhere. Economic runaways, however, relocate production due to financial concerns and the ability to complete the project at a reduced cost.

While audience reception will play a role in the development of my paper, I will not conduct polls or similar ethnographic research. Instead, I will employ news articles and similar reports of how Hollywood's move across the border has been received on either side of the $49^{\text {th }}$ parallel, from being seen as a welcome source of jobs and income to a possible "invasion" or desertion by that very same industry. In addition, this paper will not involve an in-depth examination of theories regarding national cinema in that the specific values and mores espoused in films will not be discussed; I will not be analyzing or attempting to define any sort of Canadian national cinema, a complex topic on which Scott MacKenzie has previously written. Instead, the focus will remain on the films and television shows consumed by Canadian and American audiences, and the ways in which these productions, increasingly filmed in Canada while set in the United States, shape and affect any sort of shared cultural identity.

When examining the relationship between film and cultural identity, Rey Chow writes, "If cultural identity is something that always finds an anchor in specific media of representation, it is easy to see why the modes of illusory presence made possible by film have become such strong contenders in the controversial negotiations for cultural identity" (169). Additionally, in his analysis of the development and possible defining characteristics of Canadian cinema, Will Straw states:

Margaret Atwood's Survival (1972) was perhaps the most influential of the texts produced [in seeking to establish the thematic and formal basis of national cultural traditions]. Through a detailed study of Canadian fiction, poetry, and drama, she concluded that the thematic unity of Canadian literature (in both its English and French language forms) was based on a persistent preoccupation with the notion of survival. Writers on the visual arts were very often drawn to the argument that Canadian artistic practice was marked by a preoccupation with landscape, and with the oppressiveness (as much as the sublime beauty) of nature. (524) 
Taken together, the two quotes demonstrate the problematic context inhabited by the present-day Canadian film and television audience. If what is seen on screen so greatly aids in the construction of a national identity, and if the Canadian landscape-and surviving in Canada's harsh climate-forms the basis for much of Canadian artistic motivation, what happens when the filmed landscape is inaccurate or serves as a false representation of reality?

With one-tenth the U.S. population, and at least seventy-five percent of all Canadians living within a two-hour drive of the U.S. border, Canadians have easy access to American culture, and readily consume American products. For the week of March 9-15, 2009, there were only two scripted, non-news, non-sports Canadian shows, Corner Gas (2004-present) and Flashpoint (2008-present), that ranked in the Top 20 of the most-viewed television programs in Canada-all others were American programs. ${ }^{3}$ Even more telling, "Foreign [predominantly U.S.] firms account for $46 \%$ of domestic book sales in Canada, $81 \%$ of the English-language consumer magazines on the newsstands, $84 \%$ of total revenues in the sound recording industry, and $98 \%$ of screen time in Canadian movie theatres" (Marsh and Harvey). However, when Canadians watch American television shows or U.S.-produced movies-productions set in the United States-there is a good chance they will actually see their own country on display.

According to a report on U.S. runaway productions, in 1998 Canada hosted eighty-one percent of all economic runaways-ninety-one percent of all made-for-television movies (Monitor Company). Eight years later, in 2006, "More than 200 productions were completed in British Columbia...making it the third busiest filming centre in North America after Los Angeles and New York" (Fong). Those film productions generated CAD $\$ 1.23$ billion in revenue for the province, an amount equal to the estimated value of the entire Canadian film industry in 1998 (Walker). As demonstrated by the increasing revenues, a growing number of production companies consistently choose to film movies and television shows in Canada. Approximately twelve percent of the dramas on the 2004-2005 U.S. television schedule were filmed north of the border, as were two of the films nominated for the 2005 Academy Award for Best Picture-BrokebackMountain (Ang Lee, 2005) and Capote (Bennett Miller, 2005) (Moore, F.).

Brokeback Mountain serves as an interesting case study for the Canadianization of the American natural environment as depicted on film. Based on an E. Annie Proulx short story about two ranchers who fall in love-and the complexities surrounding their relationship-Brokeback Mountain is set in Wyoming, over a period of time stretching from the 1960 s to the 1980s. Scenic shots of mountains, open skies, and rushing rivers-nature in all its stunning glory-are showcased in the film, and led to 
an increased interest in Wyoming tourism as filmgoers desired to visit firsthand the beautiful countryside they saw on the screen. Evidently, none of these people stayed through the film's closing credits, or else they would have known that Brokeback Mountain was actually filmed in the Canadian Rockies in southern Alberta, in and around Calgary and Fort Macleod.

Director Ang Lee has spoken of his initial reluctance to film in Alberta, stating that "I have always insisted on shooting my films where they are set and Brokeback Mountain is set in Wyoming and Texas so that's where I wanted to shoot." However, the film's screenwriter, having previously worked in the region, told Lee that he "couldn't find landscapes anywhere in the world better than Alberta offers" (Hobson). As a result, film production moved north and many audiences mistakenly believed the rugged, breathtaking terrain on the screen was a true representation of the iconic American West.

Similar to the West, the American Plains, the farmland is also considered hallowed ground, a region that holds a special, often idealized position in American folklore and, subsequently, in the minds of many Americans. Set in Kansas, the television series Smallville (2001-present) details the life of Clark Kent as a young man, before he became known to the world as the heroic Superman. The legend of Superman is entwined with the values he learned from his adopted parents, Jonathan and Martha Kent-two wholesome, all-American farmers from the nation's Heartland who raised their adopted child to value-and fight for-"truth, justice, and the American way." Nevertheless, Smallville is filmed in British Columbia, in the city of Vancouver and the surrounding areas. While the region can often pass for Kansas, at times it gives itself away, such as when the mountains around Vancouver appear in à wide shot, mountain ranges and vistas that Kansas lacks. Vancouver itself doubles for Metropolis, the fictional city where Superman resides. However, in Smallville, Metropolis is seen with a shoreline and port, even though it too is supposedly located within the landlocked state of Kansas. ${ }^{4}$

The fact that Smallville is filmed in Canada, and not the United States, becomes more apparent when the analysis moves from the natural environment and focuses instead on the built environment. When the Metropolis skyline is shown, anyone remotely familiar with Vancouver can readily discern such notable landmarks as the Harbour Centre Tower and Canada Place, as well as the city's predominance of glass-and-steel buildings, lending the city a very modern, streamlined appearance. One building in particular clearly heralds Vancouver's posing as Metropolis-the Marine Building in downtown Vancouver, home to Smallville's Daily Planet newspaper. Built in the 1920 s, the Marine Building is remarkable for the art deco details found on nearly every surface, from the bas-relief carvings on its facade depicting sea life and 1920s modes of transportation, 
to the lobby with an intricate marble floor featuring the signs of the zodiac, to the massive arched entranceway with two revolving doors and even more maritime-related carvings and features. The building is unlike any other, and as such is quite noticeable and distinct, standing out as a unique Vancouver signifier. The Marine Building has been in a number of feature films as well, such as Timecop (Peter Hyams, 1994), Blade: Trinity (David Goyer, 2004), Fantastic Four (Tim Story, 2005), and its sequel, Fantastic Four: Rise of the Silver Surfer (Story, 2007). While Blade: Trinity is set in a nondescript American city, both Fantastic Four films take place in New York City, an aspect quickly disproved when the appearance of the Marine Building can place all the referenced films in Vancouver.

Regardless of certain easily recognizable Vancouver buildings and landmarks, the city continues to be a leading destination for runaway productions, joining Toronto and Montreal as the major Canadian metropolitan areas Hollywood turns to for alternate filming locations. One television executive describes Toronto as the stand-in "for any big urban city," Montreal as a "'cheat' for any European-set story," and Vancouver, "with trees, snow, mountains; and vast outdoors" (Moore, F.). In a number of memorable instances, Toronto has replaced Chicago, one of the aforementioned "big urban" cities.

The Blues Brothers (John Landis, 1980) put Chicago on display, filming in such notable venues as Daley Plaza, Lower Wacker Drive, and Wrigley Field, humorously incorporating these locations into the plot of the film. However, the sequel, Blues Brothers 2000 (Landis, 1998), was filmed in Toronto and used only a few exterior shots of Chicago. Adding insult to injury, "officials from the Toronto film office called their counterparts [in Chicago] for advice on how to make their city appear more Chicago-like" (Loven). The city of Chicago was minimized even further when the 2003 Academy Award winner for Best Picture, Chicago (Rob Marshall, 2002), was not filmed in the city of its namesake, but rather, like so many other films, in Toronto.

Production crews filming in a different locale, trying to pass one location off as another, can come up against additional obstacles, beyond an out-of-place mountain range or recognizable building. As hard as they may try, set designers cannot always "de-Canada" certain filming locations. When the television series The X-Files (1993-2002) was filmed in the Vancouver area, viewers could spy cars with British Columbia license plates and gas stations selling fuel by the litre. In Harold \& Kumar Go to White Castle (Danny Leiner, 2004), as the title characters are pulling out of a strip mall parking lot, a sign for "Shoppers Drug Mart" can be seen in the background. Although the film is set in New Jersey, Shoppers Drug Mart is an exclusively Canadian chain of pharmacies; the sign's appearance easily divulges the foreign filming location. ${ }^{5}$ 
Stores unfamiliar to an American audience were a bigger problem in the recent remake of Dawn of the Dead (Zack Snyder, 2004). A mall in the American Midwest is a site of refuge for a group of people trying to survive an onslaught of flesh-eating zombies. As the survivors navigate through the mall, first ensuring the building is zombie-free and later encamping, they walk past and enter a number of different stores. While some of the establishments were false, created solely for the film, others were Canadian chains rarely if ever found in the United States, such as Roots. The appearance of the Roots sign and store poses perhaps the biggest inconsistency, as that company is closely associated with Canadaoriginating in Toronto, featuring a beaver as part of its logo, and having an extremely limited U.S. retail presence. Much like Shoppers Drug Mart in Harold \& Kumar, the Roots store in Dawn of the Dead announced to the audience that the movie was not filmed where the plot indicates.

In addition to the Canadianization of the natural and built environments featured in American-produced film and television productions, the human environment is also affected. By this, I specifically mean the Canadian actors who earn parts as extras and minor characters in runaway productions. The Canadian accent has been the subject of stereotypes and humour, as exemplified in the "Great White North" sketch from SCTV (1976-1984), a television sketch comedy show that aired in both Canada and the U.S. in the late 1970s and early 1980s. Bob and Doug McKenzie, played by Rick Moranis and Dave Thomas respectively, emphasized and personified many Canadian stereotypes, such as frequently drinking beer, wearing toques, and playing up the Canadian English pronunciation of certain words, and saying $e h$ seemingly after every other word. The sketch proved so popular that it was turned into Strange Brew (Rick Moranis \& Dave Thomas, 1983), a film that followed the exploits of the McKenzie brothers and further reinforced these Canadian stereotypes for American audiences.

These stereotypes have recently been reintroduced to a younger audience through the CBS sitcom How I Met Your Mother (2005-present). Vancouver native Cobie Smulders portrays Robin Scherbatsky, a New York journalist with a hidden past-she was a teenage Canadian pop star known as "Robin Sparkles." The program will often make the most of the character's Canadian roots; jokes alluding to Canada's brief summers (only lasting the final week of July), Canadian Thanksgiving versus American "The Real" Thanksgiving, and Canadian culture (eighties fashion not arriving in Canada until the nineties) are commonplace. How I Met Your Mother takes a page from the McKenzie brothers in overemphasizing the character's Canadian accent when Robin becomes drunk after drinking a twelve-pack of Molson beer and becoming "Super Canadian," recounting Stanley Cup highlights and referencing Tim Horton's, or in flashbacks showing the character when she was younger and still living in Canada. 
Although Canadian actors are able to suppress any stereotypically accented words, certain pronunciations particular to Canadian English still stand out. As Professor of Linguistics J.K. Chambers has noted,

Canadians pronounce the diphthong in [words such as house, couch, and about] in a singular way, so that outsiders sometimes claim that [Canadians] are saying, for example, aboot the hoose for 'about the house'. Their perception is not phonetically accurate, but what they are noticing is the higher vowel at the onset of the diphthong-phonetically, the vowel is mid, back and unrounded. The distinctive diphthong is known among linguists everywhere as Canadian Raising.... (1998 262)

While Canadian actors may be able to dampen or hide this distinctive "Canadian Raising," which had been a source of comedic material for the McKenzie brothers, other; less popularized-but no less noticeablepronunciations may slip through. Oftentimes, the Canadian pronunciation of process or professor (words beginning with "pro-") stresses a long, rounded "o", comparable to row or go. Contrastingly, Americans tend to pronounce the " $\mathrm{o}$ " in a more centralized tone (ä), similar to the " $a$ " in words such as pasta or drama. What is more, a Canadian accent leads to the first "a" in pasta or drama regularly spoken in a shortened, flat manner, such as the " $a$ " in bat or cat. Hearing words said in these distinctive ways could indicate the actor is Canadian, and while there are many Canadians who have moved to the United States seeking an acting career, if a film is produced in Canada, there is simply a greater likelihood that there will be more Canadians in the cast than if the film was shot in America. Language and accents can be an issue even when a production is set and filmed in Canada: "director Richard Kwietniowski says when he shot Owning Mahowny (Richard Kwietniowski, 2003), which actually takes place in Canada, the actors sounded funny to him and he realized it was because, even though they were playing Canadians for once, they were so used to playing Americans that they were accidentally slipping into their 'American' accents" (Hewitt). Much like buildings or skylines, language and pronunciations can just as easily reveal the true filming location, creating a disconnect between reality and fantasy, between what the audience sees and hears and the illusion the director was attempting to create.

The human element is not only a matter concerning who and what appears on the screen, but also with regards to labour-the crew members who work on actually making the finished product. The Canadian federal and provincial governments offer a range of tax credits and rebates to attract foreign film production companies. Nationally, the Film or Video Production Services Tax Credit provides a credit rate for sixteen percent of "all eligible Canadian labour expenditures" spent on creating a film or television series in Canada. On top of this federal tax credit, every province 
but Alberta provides tax credits for costs related to production, ranging from twenty-five percent of eligible labour expenditures in Ontario, Quebec, and British Columbia to fifty percent, and higher, in Nova Scotia and Prince Edward Island; the average tax credit on labour costs for the nine provinces providing such incentives amounts to just under forty percent. ${ }^{6}$ Alternatively, Alberta reimburses anywhere from fourteen to twenty-one percent of all production expenses (not just labour costs) "incurred in the course of producing a motion picture in Alberta" (Canada Film Capital).

Precedent for these types of attractive tax policies was set thirty years ago when, in 1978, Michael McCabe became the director of the Canadian Film Development Corporation (CFDC). Under McCabe, "Canada achieved the dubious distinction of being the only nation in the world to turn its film production over to 'international films' and in doing so sold itself into oblivion" (Alberta Film Development Program). Moreover, as Martin Knelman has written,

[McCabe believed] his mandate was to turn moviemaking in Canada into a profitable operation. Since it was impossible to do without major foreign sales, that meant making movies people all. over the world would shell out money to watch. If the only way to do that was to make 'Canadian' movies on home turf with Hollywood stars and frequently even with Canadian cities disguised as American cities, well, so be it. (Pratley 125)

The change in the CFDC's mission, coupled with generous federal tax incentives that allowed private investors to write-off 100 percent of their investment in certain films, led to an increase in the number of films produced in Canada as people looked to take advantage of the resulting tax shelters: "The total [Canadian film] output for 1979 exceeded 50 per cent of Hollywood's output during the same period in a country one-tenth the size of the United States" (Magder 190). This boom quickly fizzled out by 1980 in the face of mounting public outcry and the critical view that Canada was churning out inferior films-that they had chosen quantity over quality and that "McCabe had sold out, turning Canada into a dumping ground for second-rate American movies" (Knelman 37).

In more recent years, as the industry continued to migrate north of the border, so too did a number of jobs and financing opportunities. According to a 2001 industry report, "Since the June 1998 revision of the Canadian Production Services Tax Credit and other rebates and incentives, the overall value of production in Canada has risen in total dollar volume by $\$ 635$ million (154\%)" (Center for Entertainment Industry Data and Research). The same report goes on to claim, "Since the inception of the Canadian rebates, the loss of production expenditures in this segment of the entertainment industry alone has cost the U.S. economy an estimated $\$ 4.1$ billion and an average of 25,000 jobs per year" (Center for Entertainment Industry Data and Research). Due to the fact that the source of this report is 
an American industry proponent, these statistics must be taken with a grain of salt. For instance, not every job gained by a Canadian translates into a lost job in America; if not for the Canadian tax incentives, some productions would be too expensive to be made at all, resulting in zero job growth. Moreover, according to Allan King, president of the Directors Guild of Canada, "The reality is most of the pre- and post-production, advertising and marketing happens in [Los Angeles]" (MacDonald). While Mr. King is also advancing a specific agenda, his point is no less valid; the film industry has not completely deserted Hollywood, and in fact Los Angeles remains the heart of the entertainment business.

Along with financial considerations, there are a number of other reasons cast and crew would favour production moving to Canada. In the opinion of Ray Wilson, New Brunswick's film commissioner, "[Canadians] look like Americans...sound like Americans, and...know how Americans think" (Hunt). In response to the migration of Hollywood, Toronto and Vancouver have built state-of-the-art sound stages and marketed their diverse shooting locations and experienced crews and ancillary services. Further, Toronto and Vancouver can advertise their proximity to New York City and Los Angeles respectively, and the qualities they share with each of those American cities, such as a common language and time zone, making for easier collaboration (Coe 2000 393). An unusual characteristic both Canadian cities call attention to is their "placelessness," the fact that they do not really look like anyplace and can thus be "disguised as Anywhere, USA" (Lukinbeal 106). The British Columbia Film Commission in particular "promotes the province's protean nature. The region, that is, can play any number of narrative settings, depending on the needs of production" (Gasher 2002 112).

Nevertheless, Los Angeles and New York-the two largest film production centers in North America-continue to actively advocate for their cities, joined in this endeavour by politicians, actors, and unions. Citing unfair trade practices, the Film \& Television Action Committee (FTAC) "opposes 'economic runaways' that move from one nation to another purely for artificial, trade distorting financial incentives" (Film \& Television Action Committee). At a 2003 FTAC rally, California State Senator Richard Alarcon (D-Van Nuys) declared, "This is bullshit! The audacity of these people [Canadians] to come into our town to try and steal our jobs and our business. Just as we are fighting this so-called war in Iraq, we need to fight a war against those people who are stealing jobs away from California" (Hernandez). In January 2005, New York City launched its "Made in NY" campaign, offering tax credits and free outdoor advertising to film and television productions "which shoot 75 percent or more in New York City," in a further attempt to attract new productions (City of New York Mayor's Office of Film, Theatre \& Broadcasting 2005). 
Despite these efforts on behalf of American cities, Canada is not the Red Menace it is made out to be. Although the Canadian federal, as well as various provincial and city, governments offer tax incentives and other such favourable benefits, American production companies choose to work in the northern locations-Canada does not steal them away in the dark of night, as some might believe. In 2004, Representative Diane Watson (D, CA-33) wrote a letter to then Motion Picture Association of America president Jack Valenti on behalf of a number of industry unions, asking that "Universal Pictures 'seriously reconsider' its decision to shoot the Russell Crowe boxing picture Cinderella Man (Ron Howard, 2005) in Toronto" (Hunt). Unfortunately for Watson's undertaking, not all unions agreed; the cinematographers' union, for example, "[claimed] it had neither been consulted nor supported the sentiments of her letter, and added that it doubted that directors, actors or writers - all of whom continue to be hired south of the border to work on projects that shoot north of it - supported it either" (Hunt).

Whatever the efficacy of the pro-American campaigns, rallies, letters, and jingoistic blustering, the Canadian film industry has often been affected by factors outside anyone's control. Interestingly enough though, nearly every event that could be seen to negatively impact certain Canadian filming locations also served to stimulate others. Following the 9/11 terrorist attacks, the entire film industry experienced a slowdown and Canadian filming locations were subjected to a wide range of experiences and reactions. On the one hand, many productions left New York, leaving for "cheaper, less-complicated"-and perhaps safer-cities, such as Toronto (Kugler). On the other hand, though, fear and uncertainty associated with foreign travel, coupled with a desire to stay close to family and home, kept other film and television projects in the United States. Still, although Canada lost some productions that chose to remain in America, for some companies and Hollywood players, Canada was considered to be an acceptable extension of "home," able to substitute for a far-off locale while preserving a domestic sense of well-being (Associated Press).

In February of 2003, an outbreak of Severe Acute Respiratory Syndrome (SARS) occurred in Toronto, resulting in public health advisories and leading the World Health Organization to recommend limited travel to the city. Tourism declined sharply and the Toronto economy felt the subsequent impact. Additionally, the SARS health scare forced the Richard Gere-Jennifer Lopez film Shall We Dance? (Peter Chelsom, 2004) to relocate to Winnipeg before filming had even begun (Adams). While the Toronto film industry took a hit, other cities benefited, such as Winnipeg and Vancouver, which, as mentioned, already had in place a strong infrastructure able to support film and television productions and had the added benefit of being free of the SARS virus. 
September of 2007 marked the first time, since 1976, that the Canadian dollar reached parity with the U.S. dollar, and by the end of the month the Loonie would actually be valued higher than the Greenback. Obviously, this development did not happen overnight—the U.S. dollar had been steadily weakening, and the Canadian dollar gaining in strength, for years (see Appendix). However, by the Fall of 2007, the most significant reason for runaway productions to settle in Canada had all but disappeared; it was no longer economically advantageous, based on currency exchange rates, for U.S. productions to film north of the border. Tax incentives would still help draw American companies to Toronto and Vancouver, but the heady days of a time as recent as 2002, when one U.S. dollar was equal to 1.5 Canadian dollars, were long over. This in no way signalled the end of the Canadian film industry supporting American productions, however, as Canadians had long been preparing for such a scenario. In 2002, after starting construction on new sound stages in Toronto, Paul Vaughan, president and chief executive of Studios of America presciently remarked, "Our job is to create a technical facility so that should the Canadian dollar become par with the U.S. there is a reason for coming here other than the currency" (Mandel-Campbell). Setbacks and events, from the tragedies of 9/11 to the paradoxically disadvantageous strengthening of the Canadian dollar, affected the Canadian film industry in various ways, yet in all cases, American productions continued to runaway to Canada. However, as a result of the 2007-2008 Writers Guild of America strike, U.S. television networks cast their eyes across the border, searching for Canadian programming that could instead come south. ${ }^{7}$

When the Writers Guild of America (WGA) entered into contract negotiations with the Alliance of Motion Picture and Television Producers in 2007, disagreements arose over the allocation of revenue from DVD residuals and online content. Due to the inability to reach a compromise, the WGA went on strike in early November. As the weeks and months passed, new scripts and original episodes began to dwindle, forcing television networks to either air repeats or rush unscripted reality programming into production. In search of a solution, broadcasters gave a "serious look" at Canadian series, as, having been created by members of the non-striking Writers Guild of Canada, for Canadian producers, they were considered strike-proof (Andreeva \&Vlessing).

As was the case with earlier events that negatively affected the Canadian film industry, so too did the WGA strike have a silver lining. Prior to the strike, Canadian film studios were in "overdrive" as American film and television producers, responding to grumblings about a possible Screen Actors Guild (SAG) strike occurring in the summer of 2008, attempted to stockpile projects to ensure they could weather any future work stoppage. Canadians welcomed the increased levels of production, coming just as the Canadian and U.S. dollars reached an equal standing. Nevertheless, as it 
started to look like the WGA would strike, Canadians rightly worried that "a WGA strike could interrupt the pipeline of U.S. movie and TV scripts expected to be shot in Canada before SAG talks come to a head in June" (Vlessing, 2007). While the script "pipeline" dried up, another avenue of opportunity opened: in January of 2008, American television networks began to acquire Canadian programs in order to supplement their schedules. The major U.S. broadcast networks-NBC, ABC, CBS, and Fox-all followed this strategy, tapping America's northern neighbour for original, Canadian-created programming to add to their future broadcast plans. NBC procured CTV's The Listener, CBS picked up CTV's Flashpoint, Fox acquired the U.S. rights to CBC's Little Mosque on the Prairie, while the $\mathrm{CBC}$ worked with $\mathrm{ABC}$ to produce 18 to Life and sold the series Sophie to ABC Family (Vlessing, 2008d; 2008a).

Due to the actions taken by the American networks, for the first time since 1994, a Canadian series-the police/crime drama Flashpoint-was slated to air "in network prime time in both Canada and the United States" (Stelter). Although American film and television productions, oftentimes filmed in Canadian locations, continue to dominate the Canadian market, the tables are starting to ever-so-slightly turn, as Canadian programming begins to appear more frequently on U.S. television stations. Yet the question remains as to the opinions American and Canadian audiences hold regarding these shifting and seemingly interchangeable media landscapes. Flashpoint has been well received by American critics and general audiences, yet the series does not explicitly declare itself as taking place in Canada. A discerning viewer is able to notice the occasional reference to Yonge Street (the well-known Toronto thoroughfare), the Toronto skyline, or a small, black-on-grey Canadian flag patch on the police officers' uniforms. However, it is unclear as to whether or not the setting factors into the show's reception.

The concept of filmed productions using one location as a substitute for another is nothing new, and regularly occurs domestically within the United States-hosting runaway productions is not unique to the Canadian film industry. The Departed (Martin Scorsese, 2006), the 2007 Best Picture Oscar winner, was set in Boston and revolved around clashes between the Massachusetts State Police and the Irish Mob, as each organization tried to infiltrate the other. Although the movie was adapted from the Hong Kong film Mou gaan dou (Internal Affairs, Wai-keung Lau \& Siu Fai Mak, 2002), the plot resonated with Boston audiences, as connections were easily drawn between Jack Nicholson's character in The Departed and real-life Boston organized crime figure James "Whitey" Bulger. Yet despite the similarities and a plot so heavily tied to Boston's criminal element, most of the film was shot in New York City, minus a few weeks spent in Boston filming external locations and establishing shots. 
This trend is not confined to feature films or New York; the Boston-based sitcom Cheers (1982-1993), with frequent cameo appearances by Boston politicians and athletes, was filmed in Los Angeles. Likewise, the top-ranked sitcoms Seinfeld (1989-1998) and Friends (1994-2004), programs that were set in New York and incorporated much of that city's culture (sports teams, accents, neighbourhoods, personalities, etc.) into their storylines, were also filmed on California sound stages. Running counter to this stands Law \& Order (1990-present), the long-running dramatic series based and filmed in New York City. The program is known for its authentic portrayal of New York and the way it weaves the city into the fabric of its story, particularly in episodes created after the 9/11 attacks impacted New York, its citizens, and its police departmentso powerfully.

With regards to what is meant by "authentic," Lionel Trilling clarifies the term when he writes, "As we use [authenticity] in reference to human existence, its provenance is the museum, where persons expert in such matters test whether objects of art are what they appear to be or are claimed to be, and therefore worth the price that is asked for them-or, if this has already been paid, worth the admiration they are being given" (93). The definition can be moved from the museum and applied to film and television by substituting Trilling's "expert" with an audience member; when the viewer watches and considers a movie or television show, do they believe what they see? If the setting is New York City, Chicago, or Seattle, did production actually occur in that American city, or was a Canadian city used as a replacement? For a film to carry with it a sense of authenticity, for the audience to deem it worthy of such a designation, the filming locations must therefore be "what they appear to be." Any inconsistencies or seemingly innocuous "bloopers," such as inaccurate skylines, products, or signage, sabotage the filmmaker's attempt to create an authentic product.

Filming in New York allows Law \& Order to carry with it this sense of authenticity. Actors can be filmed working in Central Park or driving past local stores and restaurants, while vehicles sport New York license plates and Manhattan's 212 area code appears on signs and advertisements in the background. More importantly, in the weeks and months following 9/11, the events of that day were included in certain storylines and episodes, with one scene featuring the actors commenting on, and indicating, the hole in the sky where the Twin Towers had previously stood. The series has been labeled by the New York City Mayor's office as "a constant billboard for the multitude of unique locations that the City has to offer (City of New York Mayor's Office of Film, Theatre \& Broadcasting).

The importance of authentically representing a place can vary, however, for each person involved in production. Oscar winner Tom Hanks has stated, "It really doesn't matter where you are. It can be helpful to soak up the atmosphere of a place, of course. But, when it comes down to it, I've shot 
movies in Canada that were supposed to be Toledo or Timbuktu and, either way, it's my job to pretend I'm in a situation I'm not" (Hewitt). Oscar nominee Paul Giamatti disagrees, observing, "you can always tell when they shoot a movie in Toronto, because no matter how hard they try, Toronto doesn't really look like Chicago or New York. I shot this thing in Toronto that was supposed to be in Malibu and, as an actor, I could make myself believe I was in Malibu... but I doubt if the audience felt like they were in Malibu" (Hewitt). Actor/director Peter Berg considers filming in Canada problematic because "You end up with your feet stuck in the mud, reality-wise, even before you start shooting" (Hewitt).

Accurately reflecting a sense of a location was incredibly important to Ben Affleck when making Gone Baby Gone (Ben Affleck, 2007), a film set in and around the Boston neighbourhood of Dorchester and based on a novel by Dorchester-native Dennis Lehane. Affleck made sure to film in the area and cast locals in supporting roles. In "Capturing Authenticity: Casting Gone Baby Gone," a bonus feature from the film's DVD, Affleck asserted that filming on location in Dorchester "doesn't feel cartoony and it doesn't feel phony." Amy Ryan, one of the lead actors in the film, stated, "I have to say, one of the biggest characters in this movie is Boston and these neighborhoods. This movie could not have been shot as beautifully in Vancouver or Toronto." As discussed earlier, the casting of local actors can be problematic if their accents do not mesh with where the film is supposedly set. By casting people from where the film takes place, Affleck was able to eliminate this dilemma; according to producer Sean Bailey, "I think you should hear a lot of accents in the movie that are pretty right on, because they're truly from the neighborhood" (Affleck et al.).

A false representation of place can also affect the narrative of a film, especially if the audience is jarred by the inaccuracy: "when geographic details are botched in a movie-if the light seems too California-bright, if someone in a car covers 80 miles in a minute, if the buildings and streets just feel subliminally wrong-it makes us lose confidence in a movie" (Hewitt). If a film is shot in your hometown, it can be fun to play a game of "I Spy," trying to recognize familiar locations and areas, and perhaps any geographical liberties taken by the producers. However, if a movie is set in your hometown, yet filmed elsewhere, any geographical discrepancies have the potential to be a distraction. The reverse can happen for audience members from these runaway locations: "Suspension of disbelief is hard for movie-going Torontonians. It's simply impossible to get caught up in the moment when you're stifling the urge to announce loudly to everyone within earshot, 'That's where I take my dry cleaning!"' (Clayton). In writing about John Ford's use of Monument Valley as a filming location for nine different films, set in different areas, Martin Lefebvre states, "Monument Valley is an easily identifiable setting and is recognizable from film to film despite representing different diegetic spaces in each film. Its 
recurrence thus creates an unusual situation which strongly risks pushing the spectator of Ford's films to arrest their gaze on the space..." (Lefebvre, 49). Mismatched locales and out-of-place geographical markers threaten to grind a film narrative to a halt, as the audience becomes focused on a specific location, rather than on the plot and story occurring within that location.

The earlier Paul Giamatti quote demonstrates his concern for how an audience would perceive an inauthentic representation of a locale. For Ben Affleck, an accurate portrayal of Dorchester and its residents was essential in order to faithfully adapt Lehane's novel to the big screen. Writing about the complicated nature of film locations, Mike Gasher contends:

What is lost in audiovisual location production is a sense of appartenance [membership]; neither the industry itself nor the cultural texts this industry produces belong to the production site. The locations industry is transient. It is lured to a place, but it never belongs to that place. In the same way that producers assemble a cast and a crew, they cast a location. The producers make an economic, logistical, and aesthetic investment in the location; but, as part of a cast, it remains always a replaceable part. (Gasher 1995)

However, the issue moves beyond one of mere aesthetics, lighting, or other geographic details. When a location is constantly used to represent somewhere else, or vice versa, when a location is rarely allowed to represent itself, both places are compromised and lose a sense of identity. Regarding runaway productions, this translates into a loss of cultural identity for both Americans and Canadians. In a discussion about Hollywood productions heading to Canada, one journalist has said, "But with more and more films being shot there, the locations have begun to seem less like what they're supposed to be, and more like what they are: something recognizable as something else. It's sort of like encountering a person you mistake for someone you know, then realizing it isn't him" (Moore).

This problem of mistaken identity is exacerbated in the particular case of Canadians watching U.S.-produced films and television series. As Gasher writes, "Hollywood is not interested in telling Canadian stories or even setting its stories in Canada" (Gasher; 1995). Instead, Hollywood seems to perceive all of Canada as one big sound stage, allowing for any number of filming possibilities, so long as they can sell to an American audience. Further, in her discussion of French cinema, Susan Hayward stated, "film functions as a cultural articulation of a nation" (x). What kind of culture, then, is conveyed when the filming location does not correspond with the intended setting? What does it mean if many of the films produced in Canada feature Canadian cities and towns masquerading as some place else-typically, some place American? 
Becoming invisible, particularly in the face of an overwhelming volume of cultural material generated by America, is a constant concern for Canadians, and has been for decades. In order to attract "foreign buyers who offered more in the way of sales," Canadian producers have long felt the need "to strip Canadian content of national identifiers in favour of American equivalents" (Edwardson, 246). As previously mentioned, Canada's population is not concentrated in one place, but is instead spread out in a long, thin line along the U.S.-Canada border. This uneven distribution-a relatively small population dispersed over thousands of miles-makes it easier for Canadians to build strong cultural bonds across the north-south international border, at the cost of a weakening east-west provincial bond. In 1978, Canadian Broadcasting Corporation (CBC) President Albert Johnson, in a presentation on the alarming state of cultural affairs, reported that "English-speaking Canadian youngsters between the ages of two and eleven spend 83 percent of their television time watching American programs... They're soaking up American values, and attitudes, and history, and mythology...". In the years immediately following the conclusion of World War II, due to the fear of an American cultural domination, Canadian content quotas were established to create rules and regulations pertaining to the amount of Canadian-produced content that needed to be broadcast each day so as to preserve and reinforce Canadian cultural-values.

Canadian content standards still exist and are applied to virtually all aspects of publicly consumed cultural goods, including radio and television, yet are not without problems of their own. During the 1970s, the concept of "cultural industrialism" and marketability drove Canadianization efforts, so that, within a few years, "The individual had given way to the industry; arts organizations had been replaced by bureaucracies as the sites of cultural orchestration; the social value of the public sector had been supplanted by the economic value of the private sector" (Edwardson 252). As Ryan Edwardson notes, with regards to the aforementioned federal and provincial tax credits for labour expenditures, "One finds, for example, American film and television producers being lured to Canada with the offer of 'Canadian content subsidies' for merely employing a sufficient number of citizens in set crews, as lighting and sound technicians, and so on" (21). Thus, Canadian content regulations dictate that for a work to be considered "Canadian," the decision is based on quantitative, rather than qualitative, concerns. It hardly matters whether or not the film or television show promotes Canadian values or history, or even a general sense of Canadianness. Instead, "Tallies and statistics are presented as evidence of national cultural vibrancy when, from a more critical point of view, industrial activity cannot be equated with culture, a national sense of self, or even opportunities for domestic expression" (22). 
In light of the sheer number of American shows filling Canada's weekly Top 20 Most Watched Television Programs list, one has to wonder if any Canadian-produced series stands a chance against the imported programming. In considering the Canadian film industry, any sort of indigenous production is easily dwarfed by Hollywood's demands. What is more, "North America continues to be treated as one market in terms of the distribution rights of independent films, and Canadian companies can seldom afford to buy the rights for the whole of North America. As a result of the structure of the distribution sector, the majority of the distribution revenues from Canada flow south to the U.S." (Coe 396). Although multi-million dollar film studios are being built in Canadian cities, they are constructed more to serve the needs of American productions, rather than to foster any sort of homegrown Canadian film industry. With respect to this issue, John Barber, writing in The Globe and Mail, lamented "weren't we supposed to become ourselves at some point in this business?" (M2). If Canadians are not becoming themselves, it could stand to reason that instead, they are becoming Americans. When Canadians go to the cinema, they are often able to see their cities and towns on the screen, but only as stand-ins for American locations. Their cultural markers and identifiers are camouflaged or removed from the scene entirely, while Canadian accents and linguistic touchstones are lost, making it extremely difficult to forge any sort of identity based on the filmed representation of their society-the cultural anchor previously alluded to by Rey Chow is destroyed. With their culture treated as a nuisance or obstacle, hidden from view or concealed behind an American facade, Canadians are in danger of losing a national cultural identity altogether.

It may appear that Americans need not be as concerned about this situation as Canadians, considering it is their media that dominates other cultures. Excluding the few programs picked up by American television networks during the WGA strike, Canadian-produced film and television productions are hard to find in America, even in ancillary markets such as DVD sales. Nevertheless, Hollywood is reshaping what America looks like through how it chooses to represent American cities, towns, and rural areas on film. As a result, the America seen on the big and small screens is not necessarily authentically American, leading to confusion or even a disillusionment with the product. This uncertainty can weaken the cultural impact a film can have, possibly leading to a watering-down of the entire industry. One of the more outrageous examples of this occurred in 2003, when the USA cable network chose to film Rudy: The Rudy Giuliani Story (2003), a biopic about the former New York City mayor, in Montreal. Being the Mayor of New York on September $11^{\text {th }}$ forever linked Giuliani to that city, so for a film about his life to be filmed elsewhere destroyed any credibility and authenticity it may have once possessed. 
Chris Lukinbeal wrote that "[v]isual products, like feature films, television shows, and made-for-TV movies are economic artifacts and cultural signifiers with multiple meanings"'(2002 250). Additionally, Mike Gasher has argued that "[p]laces, and the experiences we associate with places, both as individuals and as members of a group, inform memory and our sense of belonging. This sense of belonging is critical to understanding the relationship between identity and a particular locale" and that the cinema "offers us pictures of our physical and social world, showing us where we live, with whom we share community, and from whom we are different" (2002 15). However, when these culturally important visual products no longer accurately represent the places in which Americans and Canadians live, both societies are critically harmed. In an effort to reduce economic costs, U.S. production companies have instead sacrificed cultural capital, identity, and authenticity by turning the media landscape into a series of interchangeable parts and stripping those locations of any intrinsic substance, making them barely recognizable to an audience, whatever the nationality. 


\section{Appendix}

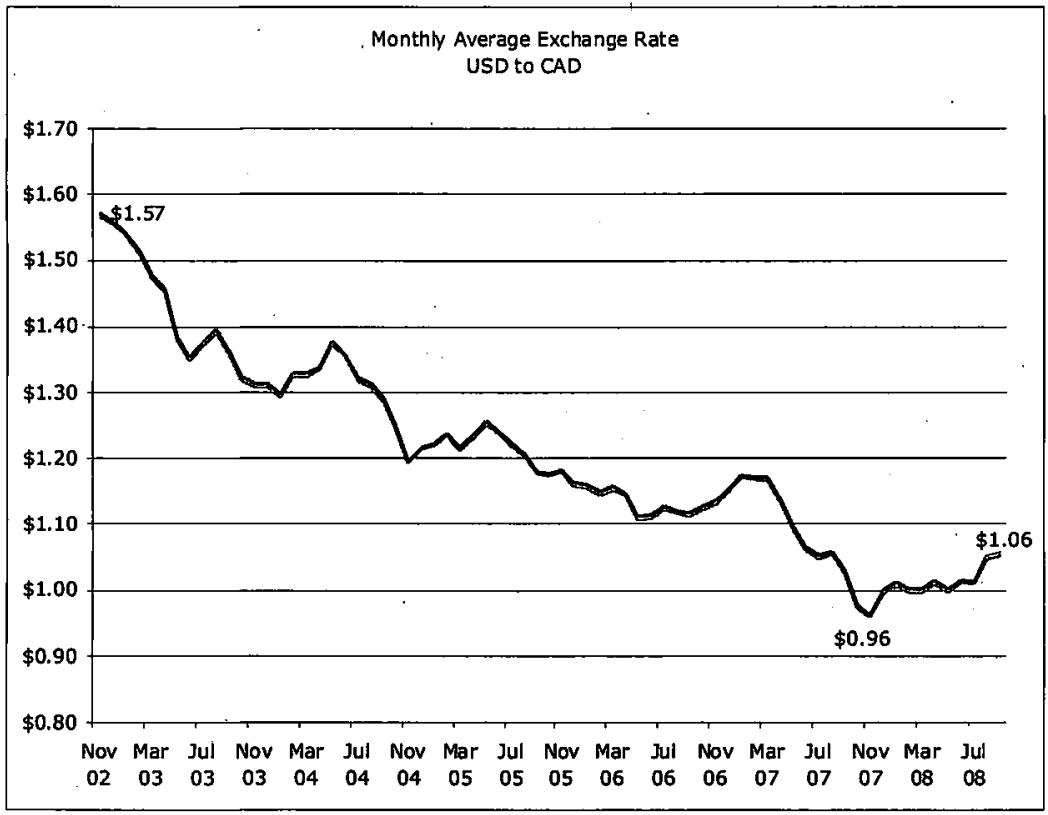

The above chart displays the monthly average exchange rate of the U.S. dollar to the Canadian dollar, from November 2002 through September 2008. Daily rates were gathered from www.oanda.com, an online currency exchange site. 


\section{Notes}

1. Recent U.S. Census Bureau surveys indicate that over 80 per cent of the U.S. population speaks only English at home, with "Spanish or Spanish Creole" coming in a very distant second. U.S. Census Bureau, "S1601. Language Spoken at Home," 2005-2007 American Community Survey, from http://factfinder. census.gov, accessed 19 March 2009.

2. It is important to note that the Canadian audiences discussed and figures given herein pertain to Anglophone Canadians and Canada.

3. BBM Canada, "Top Programs-Total Canada (English)," from www.bbm.ca/en/ top_programs.html, accessed 22 March 2009. BBM Canada rankings are similar to America's Nielsen rankings. Besides Flashpoint and Corner Gas, the only other Canadian programs consistently ranked in the Top 20 are CTV Evening News and Hockey Night in Canada.

4. Surprisingly, this unmistakable inconsistency is never addressed in the show-and in fact is highlighted, with grand, sweeping shots of the Vancouver shoreline often featured.

5. Interestingly, not only are there no Shoppers Drug Marts in the United States, there are also no White Castles in Canada, the intended destination of the film's main characters.

6. Canada Film Capital, "Canada's Film Tax Incentive Programs," May 2008.

7. It will be interesting to see how the recent economic crisis, and the growing exchange rates between the American and Canadian dollars, affects runaway productions.

\section{Works Cited}

Adalian, Josef. "CBS teams with Canada's CTV." Variety. 28 January 2008. From www.variety.com/VR1117979785.html. Accessed 5 March 2008.

Adams, James. "Toronto film folk face dry summer." Globe and Mail, 30 April 2003, The Globe Review: R1.

Affleck, Ben, Amy Ryan, and Sean Bailey. "Capturing Authenticity: Casting Gone Baby Gone." Gone Baby Gone, DVD. Directed by Ben Affleck. New York: Miramax Films, 2008.

Alberta Film Development Program. "Program Guidelines and Submission Information." June 2008.

Andreeva, Nellie and Etan Vlessing. "Nets pluck Canucks for Primetime." The Hollywood Reporter, 1 February 2008. From www.hollywoodreporter.com/hr/ content_display/international/news/. Accessed 5 March 2008.

Andrews, Marke. "Snowfall in Vancouver threatens film production! Weather makes it even harder to pass Canadian city off for San Francisco." National Post, 31 January 2007, Arts \& Life: AL3.

Associated Press. "Competition fierce for TV, film business." 3 June 2007.

. "Terrorism aftermath may curb 'runaway' film, TV production." 24 September 2001.

Barber, John. "We're a stand-in for Baltimore. Baltimore!?!?" Globe and Mail, 28 July 2007, Globe Toronto Column: M2.

BBM Canada. "Top Programs - Total Canada (English)." From www.bbm.ca/en/ top programs.html. Accessed 22 March 2009.

Canada Film Capital. "Canada's Film Tax Incentive Programs." May 2008.

$C B C$ News. "Brokeback Mountain inspires travelers to Alberta." 13 March 2006. From www.cbc.ca/canada/calgary/story/2006/03/13/ca-brokeback20060313.html. Accessed 5 March 2008. 
Center for Entertainment Industry Data and Research. The Migration of Feature Film Production From The U.S. to Canada and Beyond: Year 2001 Production Report. From www.ceidr.org, 2002.

-The Global Success of Production Tax Incentives and the Migration of Feature Film Production From The U.S. to the World: Year 2005 Production Report. From www.ceidr.org, 2006.

Chambers, J.K. "Canadian Raising." Canadian Journal of Linguistics, Vol. 18, No. 2, Fall 1973: 113-35.

- "English: Canadian varieties." In Language in Canada, edited by John Edwards, 252-72. Cambridge, UK: Cambridge University Press, 1998.

Chow, Rey. "Film and cultural identity." In The Oxford Guide to Film Studies, edited by John Hill and Pamela Church Gibson, 169-75. Oxford: Oxford University Press, 1998.

City of New York Mayor's Office of Film, Theatre \& Broadcasting. "Law \& Order." From www.nyc.gov/html/film/html/locations/sets_law_and_order. shtml.Accessed 21 April 2008.

. "Production Business Spikes Thanks to 'Made in NY'." 1 June 2005. From www.nyc.gov $/ \mathrm{html} / \mathrm{film} / \mathrm{html} / \mathrm{news} / 060105$ _prod_business_spikes.shtml. Accessed 20 April 2008.

Clark, Jayne. "Looking to climb Brokeback Mountain? Head to Canada." USA Today. 2 February 2006. From www.usatoday.com/travel/destinations/ 2006-02-02-brokeback-mountain-tourism x.htm. Accessed 5 March 2008.

Clayton, Liz. "My big fat impersonation: Toronto, Toronto that other toddling town." National Post, 7 September 2002, Toronto: TO5.

Coe, Neil M. "On Location: American Capital and the Local Labour Market in the Vancouver Film Industry." International Journal of Urban and Regional Research. Volume 24:1, March 2000a: 79-94.

- "The view from out West: embeddedness, inter-personal relations and the development of an indigenous film industry in Vancouver." Geoforum. Volume 31, 2000b: 391-407.

Edwardson, Ryan. Canadian Content: Culture and the Quest for Nationhood. Toronto: University of Toronto Press, 2008.

Elder, R. Bruce. Image and Identity: Reflections on Canadian Film and Culture. Waterloo, ON: Wilfrid Laurier University Press, 1989.

Elmer, Greg and Mike Gasher. "Introduction: Catching Up to Runaway Productions." In Contracting Out Hollywood: Runaway Productions and Foreign Location Shooting, edited by Greg Elmer and Mike Gasher, 1-18. Lanham, MD: Rowham \& Littlefield Publishers, 2005.

Film \& Television Action Committee. “About FTAC." From www.ftac.net/html/ about.html. Accessed 20 April 2008.

Fong, Petti. "Vancouver resents its place in spotlight." South China Morning Post, 10 October 2007, News: 17.

Freeman, Alan. "As Dallas stand-in, T.O. wears black hat." Globe and Mail, 14 March 2006, International News: A1.

Gasher, Mike. Hollywood North: The Feature Film Industry in British Columbia. Vancouver: UBC Press, 2002.

. "The Audiovisual Locations Industry in Canada: Considering British Columbia as Hollywood North." Canadian Journal of Communication, Vol. 20, No. 2 (1995). From www.cjc-online.ca/viewarticle.php?id=291\&layout=html.

Haysom, Ian. "Hooray for Hollywood." Vancouver Sun, 19 March 1994. Quoted in Gasher, 1995.

Hayward, Susan. French National Cinema. London: Sage Publications, 1993.

Heinrich, Jeff. "Crossing the line that defines how Canadians and Americans differ." Gazette (Montreal), 30 June 2007.

Herman, Charles. "Why is the Dollar Losing Value?" $A B C$ News, 20 September 2007. From abcnews.go.com/Business/MarketTalk/Story?id=3630951 \&page=1. Accessed 17 April 2008.

Hernandez, Greg. "Unions Protest Job Loss in Film Productions." Los Angeles Daily News, 15 November 2003, Business: B1. 
Hewitt, Chris. "Moviegoers are increasingly unwilling to buy Toronto as Chicago." Pioneer Press, 11 November 2004, Entertainment News.

Higson, Andrew. Waving the Flag: Constructing a National Cinema in Britain. Oxford: Clarendon Press, 1995.

Hobson, Louis B. "Ang Lee loves Calgary area." Calgary Sun, 14 September 2005, Entertainment: 46 .

Honey, Kim. "Locations, Locations, Locations." Globe and Mail, 22 May 2001, The Globe Review: R3.

Honey, Kim and Alexandra Gill. "Lights, camera, friction!" Globe and Mail, 22 May 2001. The Globe Review: R3.

Hunt, Stephen. "Canada vies to extend hospitality to 'runaways'." Globe and Mail, 19 April 2004, The Globe Review: R1.

Jarvie, Ian. "National Cinema: A theoretical assessment." In Cinema \& Nation, edited by Mette Hjort and Scott MacKenzie, 75-87. London: Routledge, 2000.

Johnson, Albert. "CBC Question." CBC Newsday. 4 October 1978.

Knelman, Martin. Home Movies: Tales from the Canadian Film World. Toronto: Key Porter Books, 1987.

Kugler, Sara. "Film scouts seeking locations now have to look for parking too." Associated Press, 13 June 2006.

Leach, Jim. "North of Pittsburgh: Genre and National Cinema from a Canadian Perspective." In Film Genre Reader II, edited by Barry Keith Grant, 474-93. Austin: University of Texas Press, 1995.

Lefebvre, Martin. "Between Setting and Landscape in the Cinema." In Landscape and Film, edited by Martin Lefebvre, 19-59. New York: Routledge, 2006.

Loven, Jennifer. "U.S. film industry hurt by overseas competition." Associated Press, 30 August 1999.

Lukinbeal, Chris. "Reel-to-Real Urban Geographies: The Top Five Cinematic Cities in North America." The California Geographer, Vol. 38, 1998: 64-78.

- "Teaching Historical Geographies of American Film Production." Journal of Geography, Vol. 101, No. 6, 2002: 250-260.

MacDonald, Gayle. "Canada a favourite for U.S. film producers." Globe and Mail, 29 June 1999, Report on Business: B9.

Mackenzie Hilary. "Gore orders probe into 'Hollywood North': U.S. government to track film dollars lost to Canada." Ottawa Citizen, 2 June 2000, News: Al.

MacKenzie, Scott. "National Identity, Canadian Cinema, and Multiculturalism." Canadian Aesthetics Journal, Vol. 4, Summer 1999.

Magder, Ted. Canada's Hollywood: The Canadian State and Feature Films. Toronto: University of Toronto Press, 1993.

Mandel-Campbell, Andrea. "Celluloid softwood." Financial Post, 12 November 2002, Canada: FP11.

Marsh, James and Jocelyn Harvey. "Cultural Policy." The Canadian Encyclopedia. From http://thecanadianencyclopedia.com. Accessed 17 April 2008.

Matheson, Sarah. "Projecting Placelessness: Industrial Television and the "Authentic" Canadian City." In Contracting Out Hollywood: Runaway Productions and Foreign Location Shooting, edited by Greg Elmer and Mike Gasher, 117-39. Lanham, MD: Rowham \& Littlefield Publishers, 2005.

Monitor Company. U.S. Runaway Film and Television Production Study Report. Cambridge, MA: Monitor Company, 1999.

Moore, Frazier. "TV shows are bolting from Hollywood, with many bound for Canada." Associated Press, 23 August 2004.

Moore, Martha. "Lights! Camera! Action! Stay put!" USA Today, 25 February 2005.

Moss, Linda "Superstation WGN to Pump Corner Gas." Multichannel News. 25 April 2007. From www.multichannel.com/article/CA6436326.html. Accessed 5 March 2008.

National. "The Hollywood Brain Drain." CBC Digital Archives. Aired 26 September 1996. From archives.cbc.ca/arts_entertainment/film/topics/1406-9005/. Accessed 30 March 2008.

Oanda.com. "FXHistory ${ }^{\circledR}$. historical currency exchange rates." From www.oanda. com/convert/fxhistory. Accessed 2 October 2008. 
Olive, David. "When Hollywood wants New York, it heads for Montreal." Financial Post, 6 November 1998: C05.

Pendakur, Manjunath. Canadian Dreams \& American Control: The Political Economy of the Canadian Film Industry. Detroit: Wayne State University Press, 1990.

Percy, Lily. "Breathtaking Alberta on Moviemaking Map." MovieMaker Magazine. 3 February 2007. From www.moviemaker.com/locations/article/ breathtaking alberta on moviemaking map 2532/. Accessed 5 March 2008.

Perry, Matthew, and Bradley Whitford. "Pilot." Studio 60 on the Sunset Strip. Written by Aaron Sorkin. Directed by Thomas Schlamme. Burbank, CA: Warner Bros. Television, 2006.

Portman, Jamie. "Why Hollywood heads north." Ottawa Citizen, 20 August 1999, Arts: E1.

Pratley, Gerald. Torn Sprockets: The Uncertain Projection of the Canadian Film. Cranbury, NJ: Associated University Presses, 1987.

Shonfield, Katherine. Walls Have Feelings: Architecture, Film and the City. London: Routledge, 2000.

Solomon, Alan. "Brokeback Mountain's pretend, but don't let that stop you." Chicago Tribune. 10 January 2007. From www.chron.com/disp/story.mpl/ travel/3699427.html. Accessed 5 March 2008.

Sphere Media Plus. "Sphere Media Sells First 13 Episodes of Comedy-Drama Sophie to ABC Family." 4 February 2008. From www.marketwire.com/mw/ release.do?id=817146. Accessed to 5 March 2008.

Stelter, Brian. “O Canada, Where Writer's Aren't on Strike.” New York Times, 29 January 2008. From mediadecoder.blogs.nytimes.com/2008/01/29/ o-canada-where-the-writers-arent-on-strike/. Accessed 7 March 2008.

Straw, Will. "Canadian cinema." In The Oxford Guide to Film Studies, edited by John Hill and Pamela Church Gibson, 523-26. Oxford: Oxford University Press, 1998.

Subryan, Mark. “Our Flag Gets No Mercy.” Toronto Sun, 5 October 1998, News: 7.

Tinic, Serra. On Location: Canada's Television Industry in a Global Market. Toronto: University of Toronto Press, 2005.

Trilling, Lionel. Sincerity and Authenticity. Cambridge, MA: Harvard University Press, 1972.

U.S. Census Bureau. "S1601. Language Spoken at Home." 2005-2007 American Community Survey. From http://factfinder.census.gov. Accessed 19 March 2009.

Vlessing, Etan. “ABC, Canada's CBC team for 'Life' work." The Hollywood Reporter, 29 July 2008. From www.hollywoodreporter.com/hr/content_display/ international/news/. Accessed 5 March 2008.

- . "Canada prepares for possibility of strike's end." The Hollywood Reporter, 9 February 2008 . From www.hollywoodreporter.com/hr/content_display/ international/news/. Accessed 5 March 2008.

- . "Flashpoint' sparks at CBS." The Hollywood Reporter, 30 January 2008. From www.hollywoodreporter.com/hr/content_display/international/news/. Accessed 5 March 2008.

. "Fox to build U.S. "Mosque." The Hollywood Reporter, 10 June 2008. From www.hollywoodreporter.com/hr/content_display/international/news/. Accessed 5 March 2008.

. "Looming WGA action may end Canada's film boom." The Hollywood Reporter, 30 October 2007. From www.hollywoodreporter.com $/ \mathrm{hr} /$ content_display/international/news/. Accessed 5 March 2008.

Walker, Ruth. "Canada Stands Up to Hollywood." Christian Science Monitor, 7 August 1998, Arts \& Leisure: B7.

Weinberg, Paul. "Canada: Incentives for Hollywood revive fear of cultural deluge." Inter Press Service, 5 March 2003.

Writers Guild of Canada. "Important Message to WGC Members on WGA Strike." Press release. 5 November 2007. 


\section{Filmography}

\section{Films}

Blade: Trinity. David Goyer. New Line Cinema, 2004.

The Blues Brothers. John Landis. Universal Pictures, 1980.

Blues Brothers 2000. John Landis, Universal Pictures, 1998.

Brokeback Mountain. Ang Lee. Paramount Pictures, 2005.

Capote. Bennett Miller. United Artists, 2005.

Chicago. Rob Marshall. Miramax Films, 2002.

Cinderella Man. Ron Howard. Universal Pictures 2005.

Dawn of the Dead. Zack Snyder. Strike Entertainment, 2004.

The Departed. Martin Scorsese. Warner Bros. Pictures, 2006.

Fantastic Four. Tim Story. Twentieth Century Fox, 2005.

Fantastic Four: Rise of the Silver Surfer. Tim Story. Twentieth Century Fox, 2007.

Gone Baby Gone. Ben Affleck. Miramax Films, 2007.

Harold \& Kumar Go to White Castle. Danny Leiner. New Line Cinema, 2004.

Mou gaan dou (Internal Affairs). Wai-keung Lau \& Siu Fai Mak. Media Asia Films, 2002.

Owning Mahowny. Richard Kwietniowski. Alliance Atlantis, 2003.

Rudy: The Rudy Giuliani Story. Robert Dornhelm. USA Network, 2003.

Shall We Dance? Peter Chelsom. Miramax Films, 2004.

Strange Brew. Rick Moranis \& Dave Thomas. Metro-Goldwyn-Mayer, 1983.

Timecop. Peter Hyams. Universal Pictures, 1994.

\section{Television Programs}

18 to Life. Galafilm, expected 2009.

Cheers. Paramount Television, 1982-1993.

Corner Gas. Prairie Pants Productions, 2004-present.

Flashpoint. Avamar Entertainment, 2008-present.

Friends. Warner Bros. Television, 1994-2004.

How I Met Your Mother. Twentieth Century Fox Television, 2005-present.

Law \& Order. Wolf Films, 1990-present.

Little Mosque on the Prairie. WestWind Pictures, 2007-present.

The Listener. Shaftesbury Films, 2008-present.

SCTV. Old Firehall Productions, 1976-1984

Seinfeld. Castle Rock Entertainment, 1989-1998.

Smallville. Warner Bros. Television, 2001-present.

Sophie. Sphere Media Plus, expected 2009.

Studio 60 on the Sunset Strip. Warner Bros. Television, 2006-2007.

The X-Files. Twentieth Century Fox Television, 1993-2002. 